Popa, I.A. (2021). Net art-fine art: progressive versus destructive. Scientific view on the modern problems of cultural heritage and arts in the context of social development. Klironomy, 1 (01), 150-162. Hlučín-Bobrovníky: "Anisiia Tomanek" OSVČ.

Popa, I.A. (2021). Net art-fine art: evolutiv versus distructiv. Scientific view on the modern problems of cultural heritage and arts in the context of social development. Klironomy, 1 (01), 150-162. Hlučín-Bobrovníky: "Anisiia Tomanek" OSVČ.

DOI: $10.47451 /$ art2021-05-001

EOI: $10.11249 / \operatorname{art} 2021-05-001$

The paper is published in Crossref, Internet Archive, Google Scholar, Academic Resource Index ResearchBib, JGate, ISI, CiteFactor, ICI, eLibrary databases.

\author{
Ioana Alexandra Popa \\ Doctor in Visual Arts \\ Lecturer \\ Painting Department \\ University of Fine Arts and Design \\ Cluj-Napoca, Romania \\ E-mail: ioana.popa@uad.ro
}

\title{
Net art-fine art: progressive versus destructive
}

\section{Abstract:}

The mankind has always been in search of improving its technological discoveries; as a result, culture and tradition were strongly influenced by this progress. Is there art without technique and science? There is. But as far as it is that we can make art without technique, so true is that technique improves art and even help it to develop itself. Technique generalizes, it can deny the irreductible particular cases and forms. The digitalization has made progress and can go beyond the rules that art has already been using. By introducing digital technologies in the field of making art and also selling it, we need a guidance to make it clear what kind of practices are beneficent for those who are parts of the huge mechanism of the artistic world: artists, collectors, curators, art critics, art historians and last but not least for the art loving public.

Keywords: digital, progressive, fine art, technologies, artists.

Ioana Alexandra Popa

Doctor în Arte Vizuale

Lector

Departamentul Pictură Universitatea de Artă și Design

Cluj-Napoca, România

E-mail: ioana.popa@uad.ro

Net art-fine art: evolutiv versus distructiv 


\section{Abstract:}

Omenirea s-a bazat dintotdeauna pe tehnologie, împingând totodată cultura şi tradiţia înainte. Există artă fără tehnică? Există. Însă pe cât de just este că se poate face artă fără tehnică pe atât de adevărat este că tehnica îmbunătățeşte calitatea artei şi o dezvoltă. Tehnica este un mod de a face ceva şi nu un lucru care se face. Tehnica universalizeaza ea poate nega cazurile particulare ireductibile. Digitalul experimentează mult, şi poate trece peste multe reguli apărute înaintea sa. Prin introducerea tehnologiilor digitale în domeniul artei şi a vânzării acesteia avem nevoie de un ghidaj pentru a ne fi clar ce fel de practici sunt benefice pentru cei ce reprezintă mecanismul lumii artistice-artişti, patroni, colecționari, galerişti, muzeologi, curatori, critici, istorici şi nu în ultimul rand publicul amator de arta.

Cuvinte cheie: digital, progres, arte plastice, tehnici, artist.

\section{Introduction}

We have so many directions in art that we ask ourselves which is the best or the most proper one. Which way should we follow as artists? The Renaissance in art began in the 14th century and lasted until the 16th century and it was a long and clear period. Today, art is divided into fine art with its painting, sculpture, graphics and virtual art, which in turn as subdivisions of digital art, web art, software art, etc. The young generations of artists live with one step in the past and one in the future, meaning, they use traditional art as inspiration but create their own digital art because the latter does not yet have a history of its own. In schools, they study art history including the well-known currents from Greek art to hyperrealism. Digital and urban arts are mentioned as currents but are not decanted yet. The present study follows the effects of digital art coming into being, the fact that this fact has brought something new and if it affects to some extent the plastic art as well as art in general.

Digital technology is the language of the present moment, but art has been used towards a unique direction only, in line with traditional beliefs about models of productions, creation and reception. A major representation of the digital revolution is the Web, the most popular of the Internet processes. Despite the phenomenal potential released, much of what we see on the Web in the art section is as monologic as painting or television. A feature of virtual art is the introduction of the observer inside the 360-degrees' image, which is temporally and spatially homogeneous or, at least, completely fills the visual field of the observer, to create the impression of immersion into the image. It is an illusory space determined by the rule of perspective, the definition of the image, real colors, light, proportions. In addition, other senses besides those addressed to the visual are addressed to the auditory and even the olfactory. In the landscape of rapid changes, in media technology the idea 
of the "360-degree image" will remain a continuous phenomenon in the art and media history of the 21 st century.

Abstraction Now introduces software art in most of the productions of contemporary cultural fields, offering the public enough challenging organized material to reflect on the relationship between modern and contemporary art, media, visual culture and software. If today everyone uses digital media and computers networks, we ask ourselves what exactly do we see in the Ars Electronica exhibitions? What is the phenomenon of software art or digital art or new media art or even cyber art? The key participants of this event take different positions: some call themselves designers and other consider themselves artists. Can digital art be considered a branch of contemporary art? In the 1960's modern art focused on concepts, not techniques. At that time, the artist was a journalist, looking for and showing various signs due to various media including text, photography and video. Educated in the last two decades, the 21 st century artist no longer produces painting and photographs, but projects. For the most part however, art collectors seize traditional objects that are safer as an investment.

\section{Characteristics of net art-fine art as progressive versus destructive}

Fine arts are nowadays a "working" of western culture together with the other form of art like: theater, opera, orchestral music - all of them desperately trying to survive financially through arts centers belonging to rich choice people or through governmental funds. The evolution of technique has led to an explosive art consumption.

The 21st century has witnessed a multicultural development of "mass culture" - with its thousands' competitive styles and sorts - but unfortunately, in the meantime, witnessed the rising of a so called "subculture". The mankind has always been in search of improving its technological discoveries; as a result, culture and tradition were strongly influenced by this progress.

The shamans drew their sketches in coal- obtained from the fire that was discovered, on the walls of the caves. Although those images or paintings weren't meant to have - what we nowadays consider - artistic goals, the long process of using technology to produce meaningful images had already begun. Even during antiquity, the man produced objects made of iron, ceramic, invented the parchment, wrote literature and sculpted the vaulted arches. During the Renaissance art started using elements belonging to different sciences. The Renaissance artist made use of Mathematics, Geometry, Perspective, engraving technique, oils, pressing machines, etc. Is there art without technique and science? There is. But as far as it is that we 
can make art without technique, so true is that technique improves art and even help it to develop itself. Technique generalizes, it can deny the irreductible particular cases and forms.

After re-establishing contact with the visible universe, the artist of the 1960s no longer tries to show the idea of concept in his works, but wants to transmit and present to the eyes of the viewer, the whole ensemble. The digitalization has made progress and can go beyond the rules that art has already been using. By introducing digital technologies in the field of making art and also selling it, we need a guidance to make it clear what kind of practices are beneficent for those who are parts of the huge mechanism of the artistic world: artists, collectors, curators, art critics, art historians and last but not least for the art loving public.

Research and discussions on current practice and the effort to establish forums leading to progressive activities in the digital arts should be praised and recognized. All of this is meant to encourage collectors to purchase more art in their portfolios. Throughout history, artists have created their works using a large variety of materials and methods and procedures.

Many artists of the 2000s use digital work tools and make use of a wide range of methods, the most popular being printing. The artist and the printer will certainly determine that technology to advance and, at the same time, will contribute to the discovery of new and different methods of creation in both traditional and digital art. "Before computers and laser printers, artists used tools that had not changed significantly over the course of a century. Every word included in a chart had to be engraved and picked and then, carefully attached to the right spot. The addition of various textures and colours requires the artist to prepare the layers that had to be photographically manipulated before the graphic was ready to be printed. The whole process from conception to realization often requires a whole day of work for a single graphic designer." (Fidler, 1997)

Is the computer a simple tool in creating traditional art? How does digital art adapt to the world of currant theories and aesthetics? Synthesis is the basic concept for digital art. The computer synthesizes best in relation to any other tool handled by man; the exception is the human brain, which has always been the model and basis for the development of computers. Where and how can be combine everything that has been experienced so far: originality, authenticity, objectivity, photography, randomly panted structures - materialized and reproduced to infinity, oil and water, Impressionism, Surrealism, Cubism? We no longer ask ourselves the question: What is new? But what is happening? 
Digital art has made its great entrance and has an important contribution in the developing of art in general. It has become an essential component of contemporary art. New tools are revolutionizing the way artists think. Images that could not have been done traditionally are now possible to be obtained through computer interferences. The artists of the future will not conceive a world without technology and for them the creative tools will be digital. So, we are witnesses to a crucial time in contemporary art.

Computers have not considerably reduced the time required for artists to produce original graphics, nor do they require less skill or talent than the rest of the tools used by artists. The availability and popularity of photographic manipulation created a vast and creative 'gallery' of modified images, most of which were reminiscent of what original photography used to be. Using the electronic version of the brush, filters and lenses, these "neo graphic artists" produce images inaccessible through conventional photographic tools.

Photographic manipulation is the most complex style and, at the same time, a set of techniques currently used in art. The synthesis between photographic and digital tools allows, over time, the elimination of many toxic and uncomfortable materials. This new creative technology offers advanced capabilities for reattaching and cutting - pasting portions of images from different sources; in the end, they become special collages and surreal photo-compositions. We are dealing with unprecedented manipulation and control of the colours, as well as distortion and resizing of the image. Essentially, we have an exponential field. The trend is moving very naturally towards a fast evolution of an external artistic life that also tends to develop itself logically, until all the means are exhausted, until something new is found.

The reason life seems so fast today says Saffo, is "not because individual technologies become themselves faster or because things are happening faster than they used to in the past, but because different technologies come into being at the same time. The unexpected cross impact of mature technologies is what creates the strong accelerations we feel." "Cross impacts" he says "are also variables that make forecasting new media so difficult." People wish to feel intensity - they want to experience it. Speed has become the topical trend and, if we look to not so distant future, we can probably see to collapse coming. The various art forms, in this case the communication media as well as the media enterprises are "forced to adapt and evolve in order to survive in a changing environment." (Saffo, 1992) "The only alternative would be for them to die", Roger Fiedler wrote in "Mediamorphosis" (Fidler, 1997). "Disorder is just another order and what is diffuse can be themed," 
(Levinas, 1974) confirms Emmanuel Levinas in the most logical way possible. In art the 2000s insisted on the concept of movement, relativity but also strangely, o the relationship of friendship, because it enhances the result. If I, you and another one person have the same perception of things, we must somehow gather together, said Luigi Giussani in his "The ego, the power, the works" because trying to stay united means to collaborate more, it means to be more involved in society (Giussani, 2005).

The internet art is difficult to be transposed and it is also even more difficult to be archived, due to the fact that the used technology improves and develops itself. The selling of this sort of art rises problems both for the artist himself and for the buyer. The participants in this process discussed to each other and try to find solutions. Erick Loyer monopolized by MoMA in 1998 for his project The Lair of the Marrow Monkey, stated that time, that the future could bring LCD screens to run web art just on people's walls. Nowadays we can see LCDs inside museums, as exhibits.

Alicia Miller, associated manager at SF Camerawork suggests that artists themselves should possess their own web galleries in order to keep art alive. It is assumed that keeping a digital work alive is impossible due to the fact that operating system can suffer changes every month. Some strategies for preserving digital art have certain restrictions for Net Art, for virtual works of art, but much more ambitious strategies are being developed. Time is pressing and measures must be taken if we do not want to lose the values of three decades of media and virtual art. Any political strategy developed for the collection of this type of art must necessarily involve an agreement between artists, galleries, museums equipped with the latest technology, manufacturers of technical equipment and computer centers. This was the additional reason for founding a virtual database in Berlin, which later became a tool for analyzing the digital present.

Aaron Betsy sustains the importance of the internet art and argues the collectors into acquiring as much of it as they can - quality art is a concentrated representation of our world and of our way to perceive reality (Baudrillard, 1981). "The virtual would surely illustrate the horizon of the real - as in physics we can talk about the horizon of events. But we can as well take into account the fact that all of these are nothing else but a hindrance for an indistinguishable stake." The virtual, he says "is intersecting with the notion of hyper-reality. The virtual reality, the one which would be perfectly digitized, homogenized, replaces the other reality because it is perfect, controllable and non-contradictory. Therefore, given that it is more fulfilled, it is more real than what we have established as a simulacrum." (Baudrillard, 1981)

In the 1980s, some radical theorists raised the issue of the death of painting, grounding their judgment on the assertion that advanced painting seems to show all 
the signs of internal exhaustion or it has already set limits that cannot be pushed further. When issuing these conclusions, these theorists had in front of their eyes Robert Ryman's entirely white paintings or perhaps the monotonous striped works belonging to the French painter Daniel Buren; and it would be difficult not to see their statement, in a way, as a critical judgment addressed both to the respective artists and to the practice of painting in general. However, as for Belting's idea on the end of the art, the existence of an extremely vigorous art that shows no sign of internal exhaustion is not contradictory to the idea that the age of art is not over yet.

\section{Conclusion}

The issue raised was how one practice complex gave way to another practice complex, even though the shape of this new complex was still indefinite, vague and will likely remain so.

There is no longer any plan that is foreign to the different artistic realities, and these realities themselves are no longer so distant from each other. This is happening because the fundamental perception of the contemporary spirit was formed around the principle of the museum where, any art form finds itself a place, where there is no a priori criterion of how art should look like and there is no story to refer to all the things that can be found inside the museum. Nowadays, artists consider the museum as if it did not host dead art, but living artistic options. The museum is a field that cannot be rearranged and, undoubtedly, we are witnessing the birth of an art that uses the museum as a repository of materials.

'Duchamp's Fountain - revolutionist and avant-gardist - shows that anti-art represents the absolute meaning and true dignity of art for art's sake, that the brutal abandonment of all formal conventions constitutes the absolute purism of the significant form, that the Real represents the excrement, the only one that leaves behind as its mark the absolute self-reference of art to art." (De Duve, 1989) It announced the moment when art, descended from the pedestal, would belong to everyone and some would inspire fear of the day when " everything being art, nothing will be", as expressed by de Duve. /Ready-made "(...) manages the disquieting proof of the art alienation, definitive for those who make it a certainty of decadence, temporary for those who see in it the signs of change and necessary for the ones to whom the ability to deny, promises a future emancipation" (Giussani, 2005).

Vattimo sees the phenomenon announced by Belting from a much broader perspective than the one that concerns us: he thinks the art end from the perspective of the death of metaphysics in general, respectively that of philosophical answers to 
the problems raised by a technically advanced society. So, Vattimo refers to land-art, body art, street theater and so on, cases in which the status of the work becomes essentially ambiguous: the work no longer seeks to achieve the success that would allow it to place itself into a certain constellation of values.

The third millennium catches us in a permanent chaotic change of scene. And though, it is not certain that the scene that prepares to show itself will be better than the old one. In order to create a work, it is not enough to meet people, phenomena and situations that act on, that rouse the appearance of a will, that activate the fantasy and put our energies into action. Everything must be done according to relationships that we do not fully define, which we must rather respect. There is something that must be respected, recognized, embraced, accepted, in order to create. Thus, our minds, our arms and even our hearts are imbued with a factor that may seem hostile: the effort.

The internet is here to stay: it is not to be ignored. The new computerized technology has penetrated every aspect of our lives: the way we learn, communicate, the way we create. The populist goal of the internet finds itself in contradiction with the individualistic nature of painting, the most powerful art form based on gesture, signature and originality.

We live at the dawn of a new millennium and of a new digital revolution, and today's painting reflects the promise of the moment as it analyzes his not-too-distant past.

As a conclusion, acceptance of computerized art does not require giving up classical artistic activities, but on the contrary, requires involvement in aesthetic issues through which the scientific community becomes aware of the attempts and creative possibilities. The aesthetic value does not depend on style or instrumentation, what matters is the artist's creativity and sensitivity, the form and the content of the message presented to the public. It is the choice of an expression value: language, music, image, which leads to different results. The digital art images are to be considered creative art works with a real chance to appear successful when are to be compared with traditional fine art.

As a final conclusion, the subject of this article needs further attention on short term and also long term, in order to see how things, evolve in the future, with nowadays arts.

\section{References:}

Baudrillard, J. (1981). Simulacra and simulacrum. Ed. Galilee. - New York: Semiotext. 
De Duve, T. (1989). Au nom de lárt. Pour une archeologie de la modernite. Minuit. Fidler, R. (1997). Mediamorphosis. Thousand Oaks, CA: Pince Forge Press.

Giussani, L. (2005). (ed. By Nemira). The ego, the power, the works.

Levinas, E. (1974) Otherwise than Being or Beyond Essence. - Duquesne: Duquesne University Press.

Saffo, P. (1992). And the 30 Year Rule. Designed World, 24.

Saffo, P. (Dec., 2005). Farewell informatio, it's Media Age. Retrieved January 15, 2021 from http://www.saffo.com/essays/essay farewellinfo.pdf

Saffo, P. (2008). The best forecasters will be computers. Edge Question. Retrieved Retrieved January 29, 2021 from https://www.edge.org/response-detail/10229 


\section{Appendix}

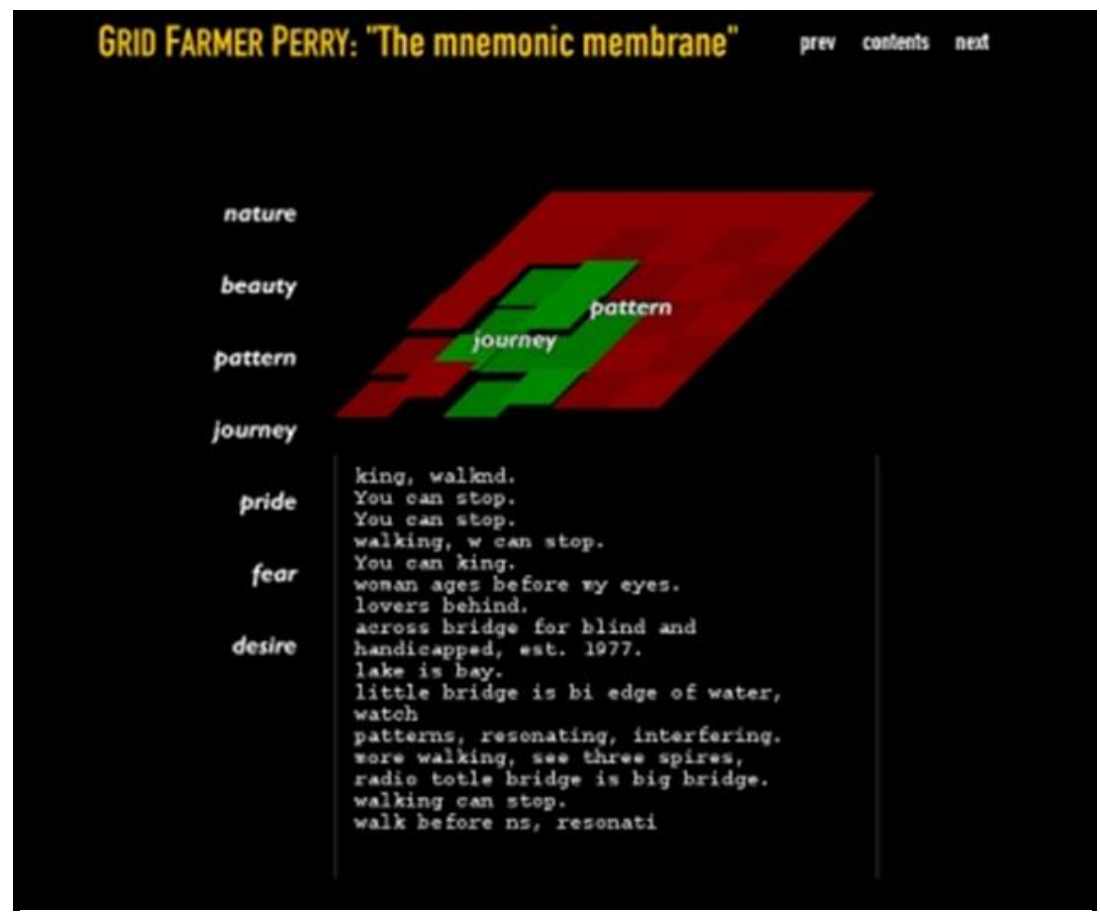

Figure 1. Erick Loyer. (1998). The Lair of the Marrow Monkey.

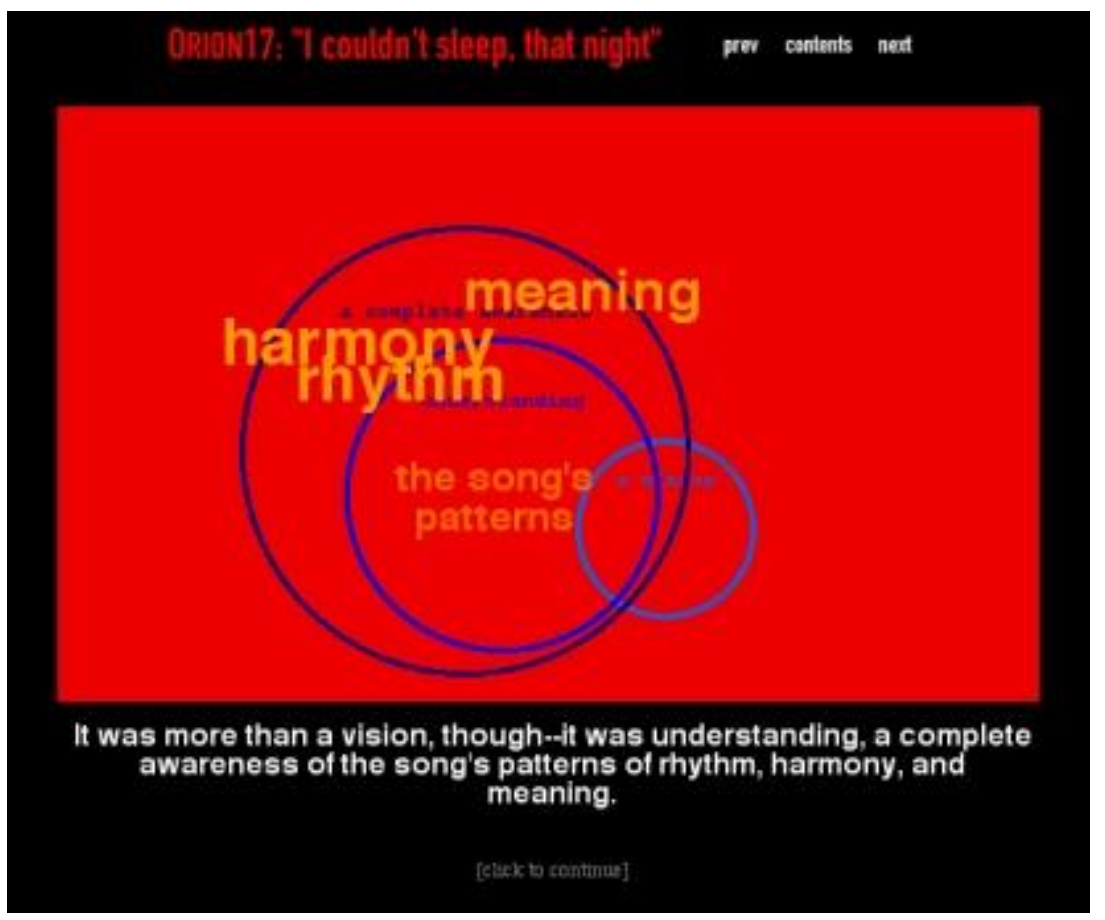

Figure 2. Erick Loyer. (1998). The Lair of the Marrow Monkey. 


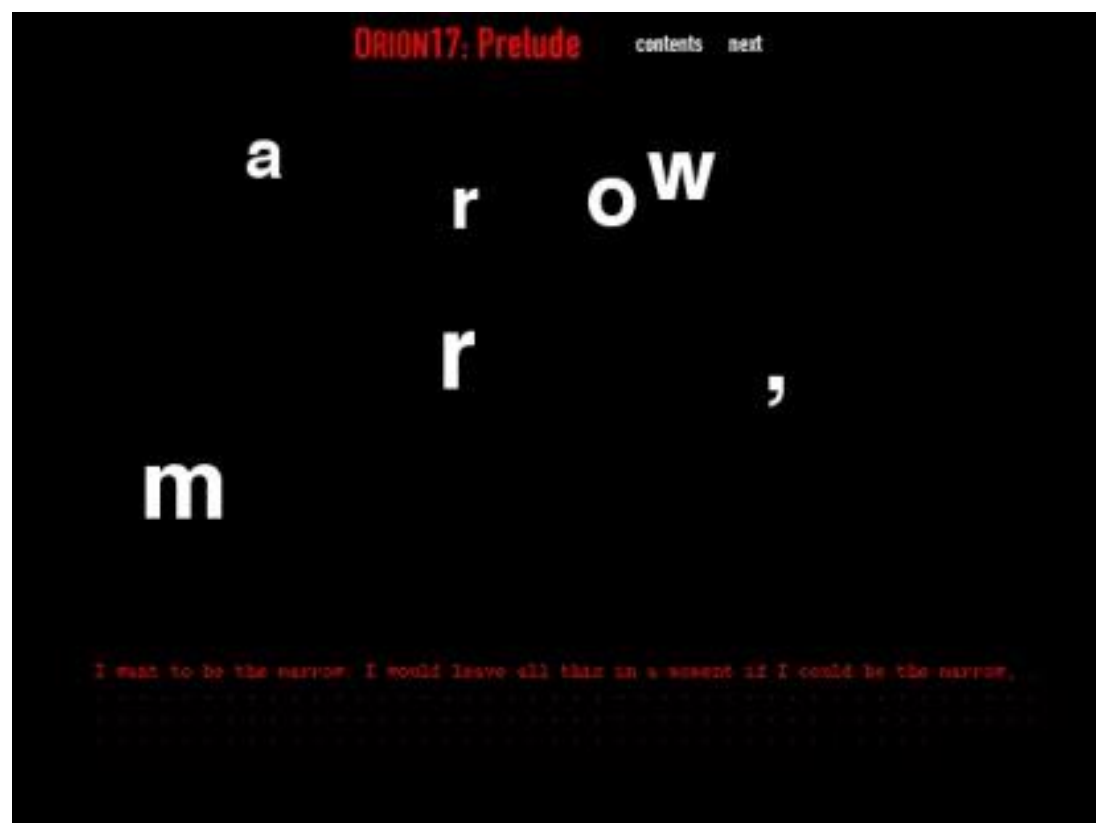

Figure 3. Erick Loyer. (1998). The Lair of the Marrow Monkey.

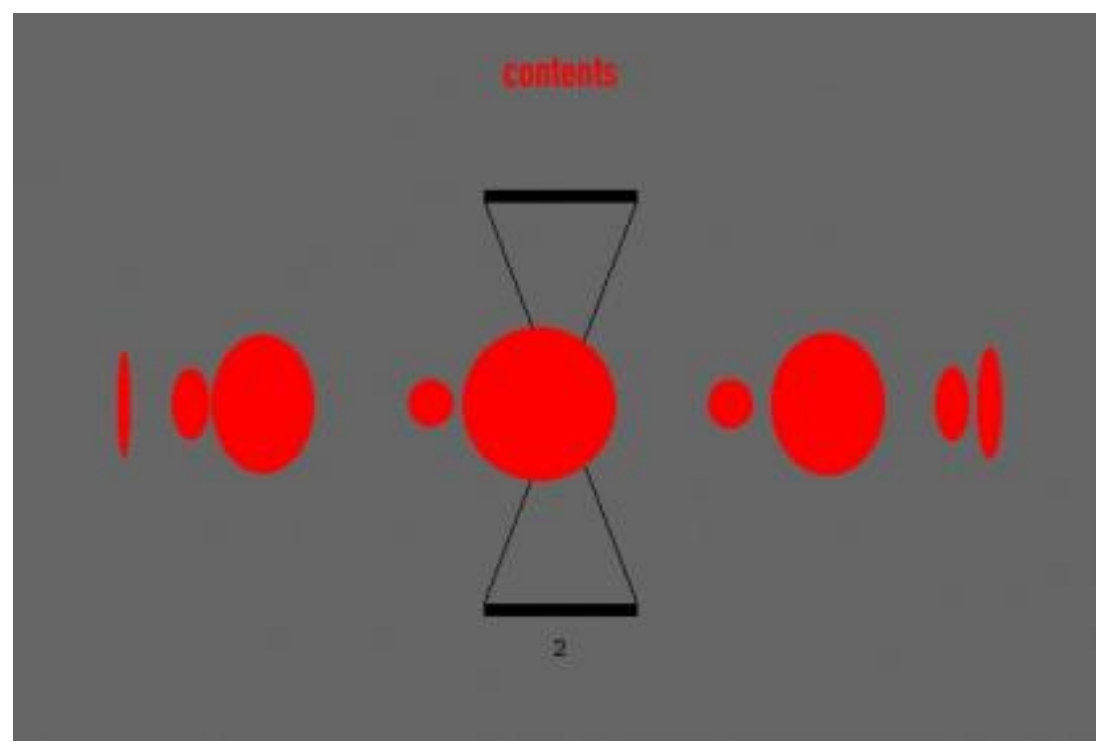

Figure 4. Erick Loyer. (1998). The Lair of the Marrow Monkey. 


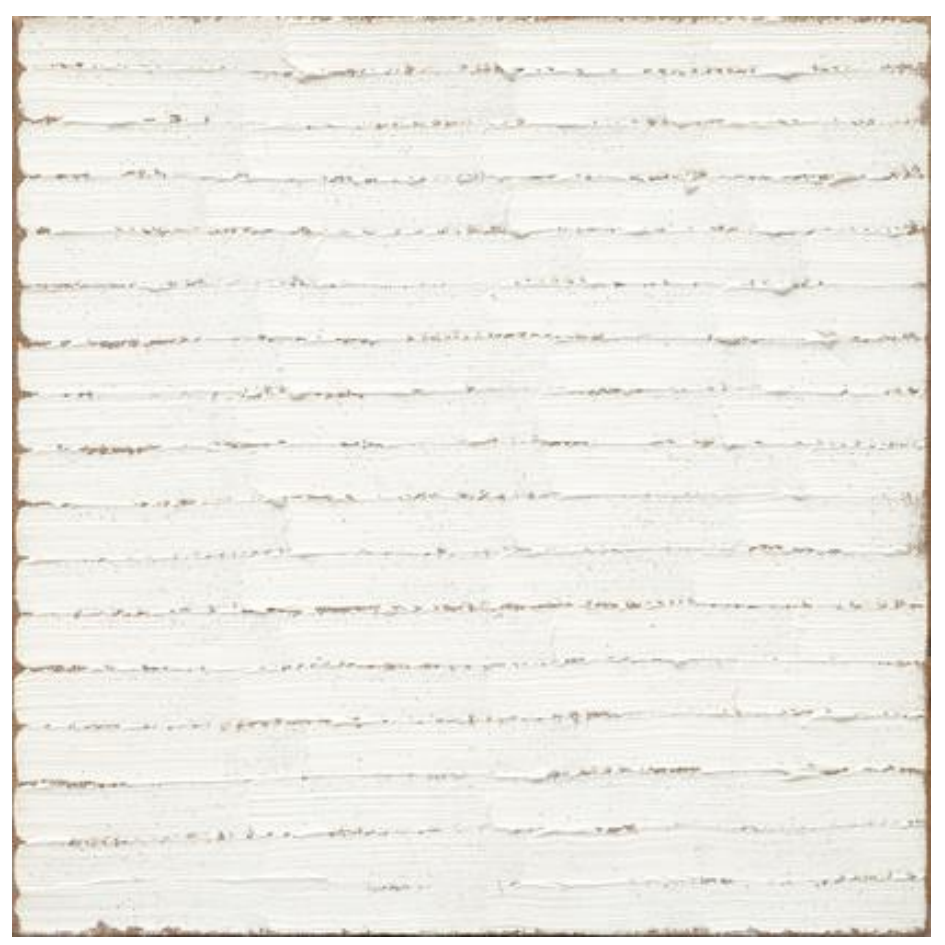

Figure 5. Robert Ryman: Untitled. 1965

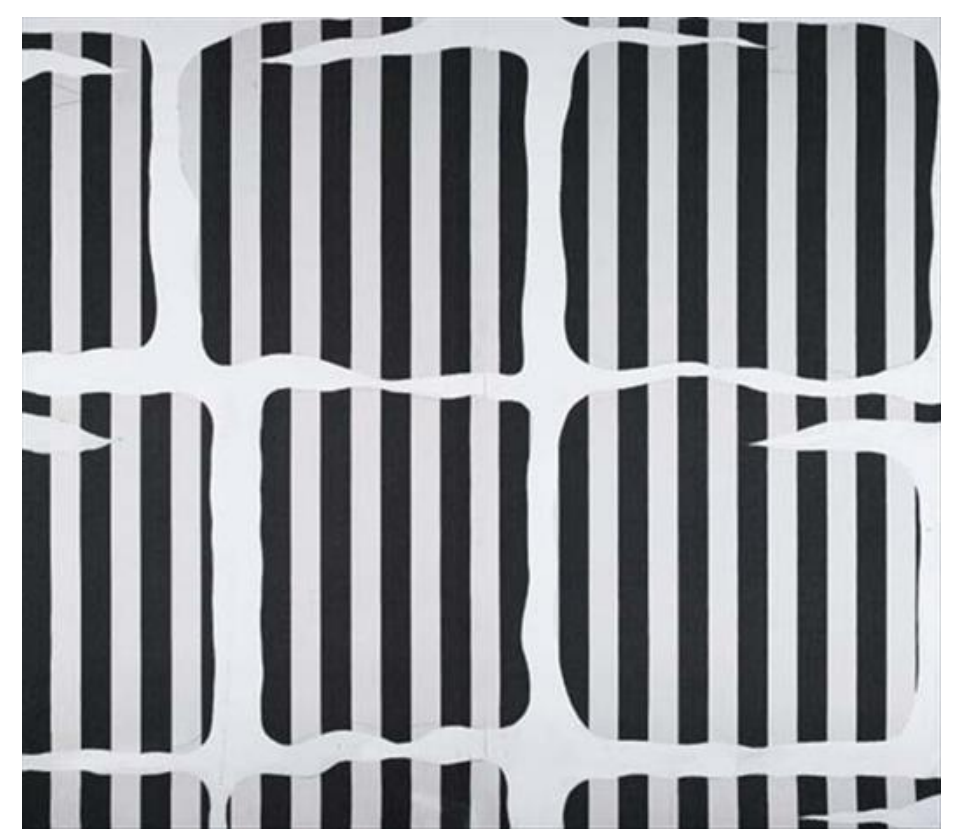

Figure 6. Daniel Buren: Peinture aux formes variables. 1965-1966. 


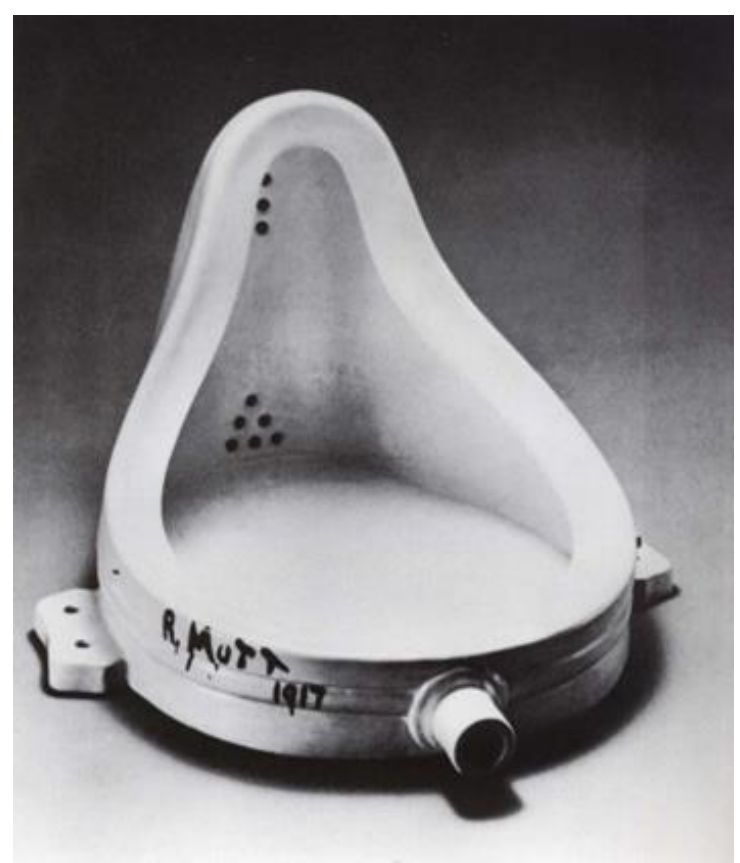

Figure 7. Marcel Duchamp: Fountain. 2008. 